\title{
Regional Features of Social Entrepreneurship Development and Georgia
}

\author{
Nino Janelidze \\ PhD student, Ivane Javakhishvili Tbilisi State University
}

\section{Abstract}

Social entrepreneurship as an event appeared in XIX century. However, the emergence, development, forms of origin, scale of activity and speed of dissemination of social entrepreneurship are uneven across countries due to objective institutional factors. Based on the analysis of the emergence and development of social entrepreneurship worldwide, we can say that social entrepreneurship is a global event, which, on the one hand, extends to all regions of the world, on the other hand, has its national forms and characteristics depending on the degree of development of institutions, traditions and cultures in any one country. In generalizing the key trends in the development of social entrepreneurship worldwide, we can infer that the temporal and geographical frameworks for the spread of social entrepreneurship are driven by objective preconditions. Historical, political and socio-economic factors have influenced the period of formation of social entrepreneurial firms, organizational-legal forms and the intensity of the spread of social entrepreneurship in different regions of the world. The article discusses the regional features of social entrepreneurship development not only in countries where it has an established tradition, but also in countries where social entrepreneurship is starting to emerge. The main objective of the presented analysis is, on the one hand, to show the global scale of this event worldwide, and on the other, to reveal its national features.

Keywords: social entrepreneurship; regional features of social entrepreneurship development

\section{Introduction}

The dominance of one or more institutions in solving societal problems in different countries, in different historical periods, has had different impacts on the formation 
of traditions, norms and customs in relation to socially important issues. For example, the main role of the Church in European countries until the beginning of the eighteenth century was due to its continued involvement in dealing with various social issues, in particular the care of refugees, the homeless and the sick. The Great Industrial Revolution, which swept through most of the world, changed the attitude towards solving social problems. The development of the role of capitalism in European countries reinforced the social responsibility of the states, which emerged largely after the world economic crisis of 1929-1933 and World War II. Most of the state budgets included social spending: education, health care, social benefits, unemployment benefits, and much more. However, after the collapse of market and state policies, relying on private equity as the main driving force for the stability and prosperity of these countries has increasingly begun. Private companies have increasingly become involved in the social aspects through various corporate social responsibility programs. The nature and preconditions for the formation and development of social entrepreneurship vary across different regions of the world. According to a study by J. Kerlin (Kerlin, Social enterprise: a global comparison 2009), social entrepreneurship operates in the US at the intersection of civil society and the commercial sector, and in Europe at the intersection of civil society and the public sector.

The traditions and customs prevalent in society tell us more about the structure and nature of acute social problems in different countries. For example in Muslim countries, there is usually no problem with orphans, as religious beliefs and the development of kinship in these countries do not allow an individual to leave a child without a family. Contrariwise in Russia, there is a problem of overcrowded child shelters. This example illustrates the importance of context in discussing the features of the development of social entrepreneurship in the world. Also, as J. Kerlin (Kerlin, Social enterprise: a global comparison 2009) points out that by defining the boundaries and understanding the essence of the event, "social entrepreneurship" must necessarily be realized by joining it to the regional context.

\section{Developed countries - Europe}

Social entrepreneurship emerged in Europe as early as the nineteenth century, when the development of the so-called "social economy" began with the active growth and strengthening of the non-profit sector, the main agents of which were cooperatives, mutual organizations, Associations and funds (Арай, 2010)

At the end of the 20th century, most European countries faced social, employment, health and education problems that required immediate resolution. These problems were practically impossible to be solved only by the government and the private sector, which is why the activities of non-profit, civil and local community organizations were intensified during this period. Gradually, nonprofit organizations began to diverge from their core function - protecting the interests of certain strata of the population, becoming increasingly involved in the production of goods and 
services, requiring an entrepreneurial approach to achieve efficiency and financial stability.

Nowadays most social European enterprises are operating within the traditional third sector legal framework. They are formed in the form of associations, alliances where the law is relatively loyal, although in countries where the law is relatively strict and restricted to third sector economic activity (eg Northern European countries) Social entrepreneurship occurs as cooperatives (A map of social enterprises and their eco-systems in Europe, 2015).

Figure 1.1 Countries with specific legal forms or statutes for social enterprise

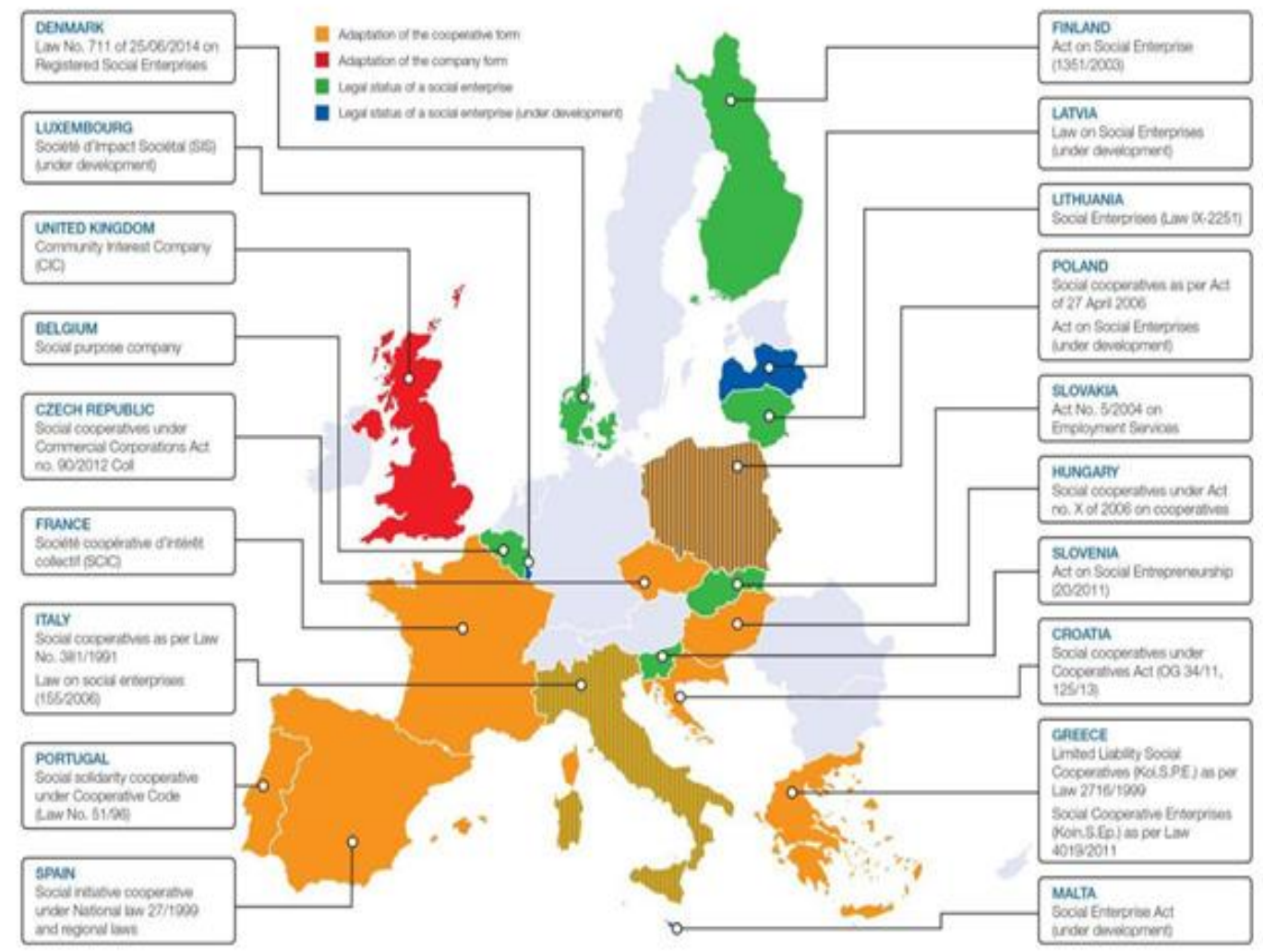

Source: file://C:/Users/User/Downloads/Synthesis\%20report\%20FINAL.pdf

The first country to regulate the activities of social enterprises was Italy, where in 1991 such enterprises were given the official status of "Social cooperatives". In 1995, the Law on Companies with Social Mission was adopted in Belgium. An entirely new form was adopted for social entrepreneurship organizations in the UK in 2001 by a 'community interest company'. However, it should be noted that "most of the social 
entrepreneurs in Europe still function in the traditional legislative framework as the 'third sector' (Social Enterprise: New Model for Poverty Reduction and Employment Generation 2008).

EU initiatives to support social entrepreneurship programs and research play an important role in creating favorable conditions for the development of social entrepreneurship in European countries. International foundations, associations and organizations (USAID, Ashoka Foundation, EMES European Research Network) also play an important role in the development of social entrepreneurship in European countries. Speaking of social entrepreneurship, it is important to note that unlike the US, where social entrepreneurship is studied both in business schools and in the faculties of sociology, in Europe social entrepreneurship research is mainly conducted by sociologists, which shifts the research vector from economic to social.

\section{North America}

Social entrepreneurship in the U.S. and Canada is viewed in a much broader context than in other countries. The notion of "social entrepreneurship" encompasses a continuum of socially oriented organizations: ranging from commercial organizations involved in social responsibility to non-profit organizations. Such a broad understanding is due to the historical context of the formation of social entrepreneurship in Canada and the US (Арай 2010).

By the end of the eighteenth century, commercial activities in non-profit organizations in the United States were legalized and virtually comprehensive. For example, religious and community groups owned markets and, along with voluntary contributions, also sold household goods (Kerlin, Social entreprise in the United States and Europe: understanding and learning from the differences 2006). In the 60s of XX century, the US government developed the Great Society program, under which the federal government invested billions of dollars in assistance programs for the poor, in education, health care, public development, the environment, and the arts. Many funds have operated through non-profit organizations to avoid unnecessary bureaucracy, which has led to an increase in the number of non-profit organizations (Kerlin, Social entreprise in the United States and Europe: understanding and learning from the differences 2006). However, the economic downturn In the 70s and 80s of $\mathrm{XX}$ century led to a decline in federal programs, reflecting the financial stability of nonprofits that began looking for other sources of income instead of donations. This is how active development of income-generating socially oriented activities in the United States began. 
It should be noted that the institutional environment of social entrepreneurship in the US is mainly formed by private foundations that provide financial support to carry out educational, training, advisory services, provision of social entrepreneurs (unlike, for example from Europe, where these functions are performed by the state, or public organizations). Support for social entrepreneurship in the United States by private equity funds began in the 60s of XX century. Some foundations (the Kellog Foundation, the Kauffman Foundation, the Rockefeller Foundation) focused on the formation of a network of social entrepreneurs, others supported startups with social missions (Roberts Enterprise Development Fund). International funds, engaged in social entrepreneurship consulting, training and retraining as well as grants to social entrepreneurs have gradually emerged (Skoll Foundation, Ashoka, Schwab Foundation). Research centers, universities (The Fuqua School of Business, Duke University, Harvard Business School, Columbia School of Business) play an important role in the development of favorable conditions for social entrepreneurship in the United States, also associations of practitioners in the field of social entrepreneurship (Social Enterprise Alliance, SeeChange, National Gathering for Social Entrepreneurship).

Social entrepreneurship in the US encompasses many areas and sectors - "from profitable micro-lending institutions designed to provide small business financing to non-profit pharmaceutical companies seeking to improve the health of the population" (Fostering social entrepreneurship: a comparative study : a summary of recommendations for governments, policymakers and social entrepreneurs in Brazil, Germany, India, Poland, UK and USA: paper presented at the World Economic Forum in Davos 2006) Depending on the goals and objectives of organizations, US law allows for the choice of the appropriate legal form.

Differently from the United States, where historically the foundations and foundations of civil society have a strong position in solving social problems, the Canadian government has been pursuing a "welfare state" since World War II. Using the principle of shared justice, the Canadian government seeks to overcome economic and social barriers to achieving "common good" by minimizing social differences and discrimination (Арай 2010). Community economic development initiatives (CED)1 have been actively developing in the country for the last 30 years. In the US and Canada, there are various forms of inter-sectoral interaction that ensure the effectiveness of social policies. Social Innovation, Social Entrepreneurship Research

Socio-Economic Development Network (CED Network) - uniting individual citizens and organizations to create favorable economic opportunities and social conditions, especially for vulnerable groups of the population. 
Centers play an important role in Canada's overall focus on social entrepreneurship Operating in universities (eg John Molson School of Business, Concordia University, Montreal; Rotman School of Business, University of Toronto; Universitéde Québec àMontréal, Faculty of Management; Mcgill School of Management), associations (eg, Canadian Community Economic Development Network; Chantier de l'Economie Sociale). (e.g., Canadian Community Economic Development Network; Chantier de l'économie Sociale).

\section{Developing countries - Asia}

When discussing social entrepreneurship in Asia, one must bear in mind that this is a region where $60 \%$ of the planet's population lives, but the socio-economic situation in many Asian countries is unstable. It is precisely the environmental, social and economic imbalances in this region that have catalyzed the use of innovative approaches to problem-solving. The formation and development of social entrepreneurship in Asian countries was uneven. The beginning of the mass development of social entrepreneurship in Asia can be traced back to the 1990s, when social entrepreneurial firms emerged in Asian countries.

The first socio-entrepreneurial firms emerged in Asia in the absence of sources for capital raising. The only way to do business was either the entrepreneur's own funds, and / or grants. Funders and religious organizations were usually the grantees. The role of foundations in shaping and further developing social entrepreneurship in the world is undeniable. After achieving social and economic stability in Europe, European funds began to allocate funds to support Third World countries (Арай 2010).

The main religions of countries such as Indonesia, Pakistan, Bangladesh, Malaysia, are Muslim. According to Muslim traditions, all believers who own more than others are obliged to offer alms once a year. "Zakat". The funds raised have opened many social enterprises in Asian countries (https://www.zakat.org/en/).

In addition to the major funding sources discussed above for social entrepreneurship, the development of non-profit organizations focused on earning income has also begun in Asian countries. For example, a non-profit organization whose main activity is to protect children's rights in India has started selling postcards and stationery to support the organization's core business. Gradually, many non-profit organizations became financially more stable at the expense of forming their own sources of income (https://www.muslimaid.org/). The trend of recent years has been to change the legal status of financially stable non-profit organizations and to transform the charity 
from an organization into a socially oriented enterprise. Social entrepreneurship can be found in virtually every aspect of the economy in Asian countries - education, healthcare, media industry, transportation, insurance and more. India should be selected from Asia, where social entrepreneurship has a rich history. The sociocultural traditions of India have always promoted social entrepreneurship and promoted societal initiatives through various forms such as philanthropy, free trade, inclusive business models. The brilliant period of the development of social entrepreneurship in the country was the period of Mahatma Gandhi (1921-1934), when numerous socially oriented enterprises were set up that are nowadays clearly within the framework of the generally accepted definitions of social entrepreneurship (https://in.thehackerstreet.com/social-entrepreneurs-2/).

Nowadays, in light of the rapid economic development in India, social problems have also been exacerbated (the gap between rich and poor, between urban and rural population is increasing). Many large companies are focusing on programs to support vulnerable populations and build their businesses based on the concept of a "pyramid foundation". For example, one of India's largest Tata corporations has not only developed a number of products for the "pyramid seabed", but has also created several social enterprises that address important societal problems (http://www.tatasechallenge.org/).

Corporate interest in social entrepreneurship has not been driven by the state's reluctance to address social problems. The Government of India is taking a proactive stance in support of social innovation. The National Innovation Council, which supports innovation projects, including in the social field, plays an important role in this regard. Today we can talk about the existence of an entire 'ecosystem' of social entrepreneurship in India, which includes educational institutions, social networks, government institutions, foundations, venture capitalists, etc.

A distinctive event in the development of social entrepreneurship in Asia was the creation of Grameen Bank in 1976 by Muhammad Yunus, who provided loans to the poor people of Bangladesh (their daily income does not exceed \$2) without taxes and interest rates (https: //en.wikipedia.org/wiki/Grameen_Bank). Subsequently, other services in the field of microfinance also emerged and began active microfinance development around the world as an effective socially oriented business. The creation and distribution of microcredit in Bangladesh, India and later in other Asian countries, has been made possible by the close interconnected traditions of these societies where rules are considered wrong. 
Social Entrepreneurship for China - is a fairly new phenomenon that "nowadays lacks strength and lacks a clear framework for development" (The general report on social enterprise in China 2008). The widespread use of the term "social entrepreneurship" in Chinese society began only at the beginning of the 21st century, when David Bornstein translated "How to Change the World: Social Entrepreneurs and the Power of New Ideas" in Chinese 2004) and Charles Leadbeater's The Rise of the Social Entrepreneur (1997). It was then that social entrepreneurship became the topic of discussion at conferences, seminars, roundtables with the participation of nonprofits, scientists, and the mass media. The essence of "social entrepreneurship" is so uncertain in Chinese consciousness and research that according to a British Council report "only a small proportion of firms that consider themselves to be social enterprises can be considered as such" (The general report on social enterprise in China 2008).

Among the factors hindering the development of social entrepreneurship in China, we must definitely state policy that does not create favorable conditions for the development of non-profit organizations. Only in 2011, as stated in the Skoll World Forum 2011 (http://skoll.org/skoll-world-forum/about/). The situation in the social sector showed positive trends - the number of private funds exceeded the state, increasing private equity participation in solving social problems. Although philanthropy is not typical for China, the tradition of donations is widespread, playing a major role in helping the community to realize and support social initiatives. G.Dizzy, professor of the university of Fuqua Duke which is director of the Center for Spreading Social Entrepreneurship, thinks that for the past 30 years, China has shown that it is capable of building new institutions and instruments quickly enough. If the process of building the infrastructure needed to support and stimulate social entrepreneurship continues, then China will be able to set an example for the whole world (Dees 2001).

The strong impetus for the development of social entrepreneurship in Southeast Asian countries became the economic crisis, that spread to the region in 1997. The economic crisis has exacerbated the social problems of society - unemployment, social inequality. In pursuit for a solution to the crisis, along with the introduction of programs, governments in Southeast Asian countries have begun to consider social entrepreneurship as one of the most important mechanisms for addressing social problems. Based on experiences in North America and Europe, governments have begun to introduce mechanisms to support social entrepreneurship (Арай 2010). 
The policies of many Asian countries today are aimed at supporting social entrepreneurship. For example, in the Republic of Korea, the government views this event as an effective way to create additional jobs and provide social services, which is why it gives social entrepreneurs preferences when delivering goods and services to public institutions. In 2006, the government developed an ambitious action plan in support of social programs Social Dimension 2030 (Social Vision 2030), which provides such firms with state support for decent competition in market conditions. The British Council, Ashoka Foundation, Schwab Foundation, Creative Grammy Lab, which runs a range of educational programs in the field of social entrepreneurship, organize various seminars and conferences in the Asian region. In 2010, thanks to the initiative of Muhammad Yunus, a Declaration on the Establishment of a Social Business Hub in Asia1 was signed in Fukuoka, Japan (https://startup.fukuoka.jp/). The main objective of the Hub is to promote the development and dissemination of social business ideas in Asia.

\section{Latin America}

The opportunity to involve vulnerable groups in the process of supplying goods and services to disadvantaged populations, as well as market tools and resilient business models, has also been discovered in Latin America. Latin America has a high rate of poverty, which implies a myriad of social problems (restricting access to social services for poorer populations, health care, education, high levels of crime, income disparities, etc.) [https://www.ashoka.org / en / story / promoting-socialentrepreneurship-latin-america]. While the number of poor residents in Latin American countries has been declining for the past 15 years, the degree of socioeconomic inequality remains high. Thus, according to the Commission for Economic Affairs of the Latin American and Caribbean States (Comisión Económica para América Latina y el Caribe), this region is considered to be the most "unequal" in the world (Арай 2010).

An important feature of the socio-economic situation in Latin American countries is the so-called "Social Exclusion". In the context of Latin America, this term may be interpreted as a process when individuals or groups are deprived of market opportunities. Various barriers and constraints hinder the less well-off population from becoming independent agents of financial-economic relations. Even under the pressure of international organizations and associations, even in the face of escalating

In 2011, the city of Fukuoka was awarded the title of "City of Social Business". The first city to receive this title was Wiesbaden (Germany) in 2010. The title was suggested by the Creative Lab Grammin, an initiative supported by many social or political organizations that have officially demonstrated their involvement in the development of the idea of social entrepreneurship. 
social tensions, lately various projects of engaging the poorest class of the population in Latin America have slowly emerged.

Social Entrepreneurship, as the interaction of vulnerable class of the population, is actively developing around the world, but in Latin America we can only talk about the initial phase of social entrepreneurship formation and development (Social enterprise: making a difference 2006).

Social entrepreneurship in Brazil, as in the rest of Latin America, has emerged relatively late. According to the 2009 Global Entrepreneurship Monitor report, early socially oriented entrepreneurial activity in Brazil is one of the lowest and almost 6.5 times lower than in China (Global Entrepreneurship Monitor 2010) ${ }^{3}$. In Brazil, the SEA is 0.4\%; In China - 2.6\% (Global Entrepreneurship Monitor 2010). As the most dynamically developing country in Latin America (average annual GDP growth over the last 10 years - 3.2\%), Brazil is one of the first countries in the world in terms of social inequality (Human Development Report 2006). There are many social problems in the country that are not resolved by the state and at the same time are increasingly becoming the focus of socially oriented businesses. Problems with discrimination, environmental pollution, and access to essential services such as medicine, education, have become areas where social-purpose entrepreneurs not only create social values but also achieve economic outcomes. It is important to note that the Brazilian legislative system supports private initiatives, including the socially oriented ones. For example, there are a number of tax and credit benefits for social enterprises. However, benefits are provided by public authorities as a quick response to existing social problems that require immediate resolution, which is why these processes are not consistent with the state and, in turn, make it difficult to understand and apply. In Brazil, a more favorable environment for social entrepreneurship is gradually emerging thanks to active venture capital formation and active involvement of foundations, educational institutions, associations (eg SEKEM, Ashoka McKinsey Center for Social Entrepreneurship), which are engaged not only in education and consulting but also in Financial support for social entrepreneurs is also pouring in. According to the research of the Aspen Network of Development Entrepreneurs (Brazil), in 2011, among the founders of social enterprises that took part in the survey, $72 \%$ were from the poorest population, with households earning about $\$ 680$ a month. Thirty-six percent of these organizations focused on women's rights, $30 \%$ on children's and adults rights, and $16 \%$ on helping people with disabilities (www.nbfund.ru). 
Nowadays, the Latin American countries face an important task - to increase the scope of social entrepreneurship activities by creating favorable conditions for publicprivate partnerships that benefit all parties. In Latin America, associations - the Social Enterprise Knowledge Network and the Sustainable Development Fund (Fundación para desarrollo sostenible (FUNDES)) play an important role in shaping social entrepreneurship.

\section{Africa}

It is clear that for African countries where most of the social problems remain without the attention of the state and the private sector, social entrepreneurship may become the driving force that would not only solve specific social problems of society but also initiate social transformation of these countries. However, the authorities of a number of African countries, which regard social entrepreneurs as people of risky nature and do not pursue their activities as "free thinking efforts", are directly involved in social entrepreneurship (Urban 2008). The inability of the state to cope with the many contradictions in society and the unawareness that the "invisible hand of the market" cannot handle the situation by what would be the best public option (Christie and Honing 2006), is further aggravated by the fact that the state restricts the freedom of activity of socially oriented organizations. For example, the state's "restrictive" policy towards nonprofits is due to the fact that, first of all, nonprofits have a great deal of potential in non-governmental structures, Secondly, non-profit organizations, with the change in donor policies for the creation of civil society institutions, may receive funding that would otherwise be directed to government projects (Sesan 2006).

In the face of resistance to financial instability and reliance on external funding, nonprofit organizations have attempted to move to a new model of functioning that will ensure their financial stability. Thus, the first social enterprises emerged among nonprofit organizations in African countries at the end of the 20th and early 21st centuries (for example, the FATE Foundation (2002); Lagos Digital Village (2004)). active work of international associations supporting social entrepreneurs (Ashoka and Schwab funds) provides a conducive environment for the development of social entrepreneurship and has a positive impact on the formation of institutional foundations for social entrepreneurship in Africa through the organization of various conferences, educational programs About Yale Entrepreneurship. 1

\footnotetext{
${ }^{1}$ In 2011, the International Forum of Social Enterprises (The Social Enterprise World Forum) was held in South Africa. The Italian School of Business at Altis and Sacro Cuore University (ALTIS Postgraduate School of Business and Society, Universita Catholica del Sacro Cuore) implements MBA programs in Kenya in the field of social entrepreneurship.
} 


\section{Georgia}

For Georgia, social entrepreneurship is not a new phenomenon, but its active development began only at the end of the 20th century. Since the post-Soviet period, there has been an increase in private initiatives in the social sphere that were previously largely locked in by the state.

The researcher conducted a survey in September-November 2019 to determine the degree of awareness of social entrepreneurship as an event in Georgia. The methodology of the study was to conduct random interviews with residents of the capital from 18 to 70 years old through direct interviews. A total of 200 respondents were interviewed. At the initial stage a research instrument - questionnaire was developed. Based on the survey data we obtained, the result showed that only $9 \%$ of the population said they knew what social entrepreneurship meant.

Do you know what the term "social entrepreneurship" means?

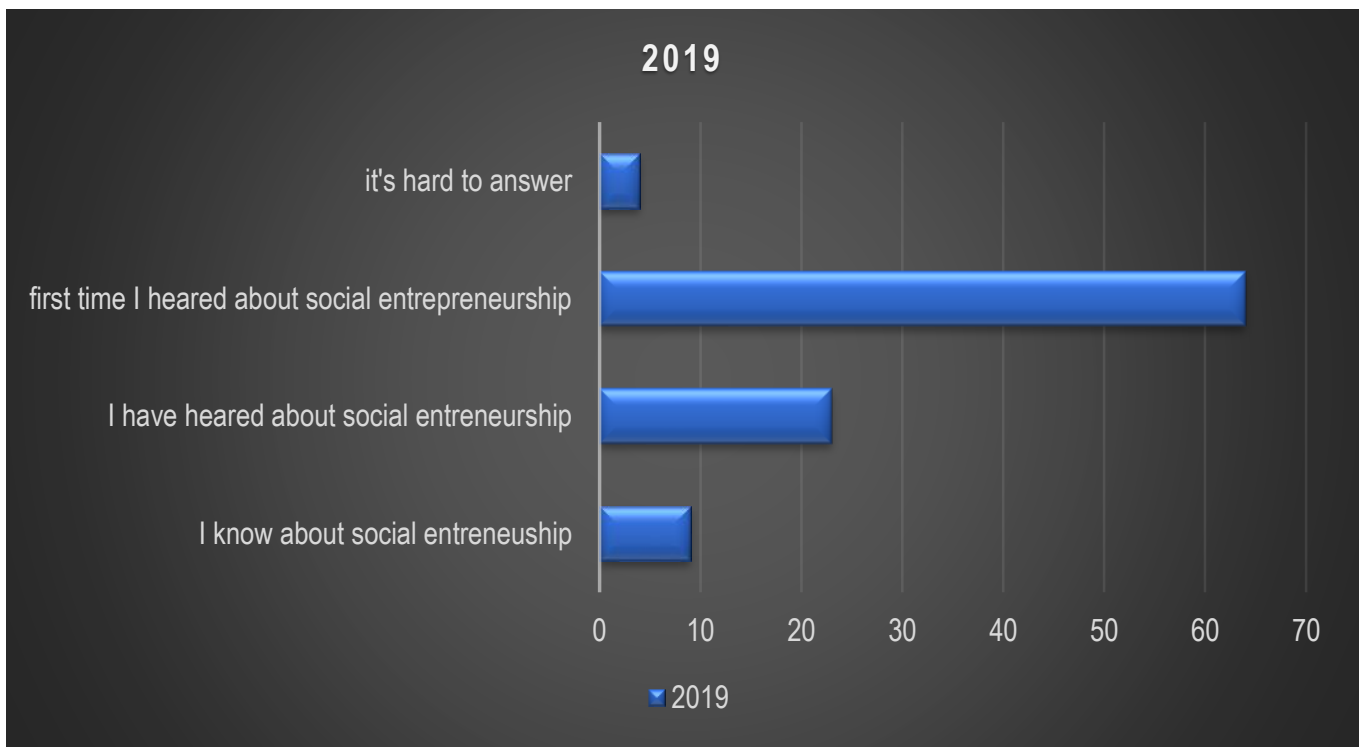

Figure 1.2 Population Awareness of Georgia on Social Entrepreneurship Source: Author, 2019

Georgia, as with all transition economies, is characterized by a lack of legislative framework, which explains the low effectiveness of socially oriented organizations.

There are not so many examples of social entrepreneurship set up in Georgia today at the organizational level so far as to speak of an already established trend, but there are some successful initiatives that have taken off and are actively developing. 
With regard to social entrepreneurship activities in the real world and the scale of measurement, including Georgia is very difficult, the indicators, such as the awareness of the phenomenon of the structure supporting the existence of a legal framework, this event shows the degree of development and institutionalization of this event in a particular society. It is important to note that there is no definition of social entrepreneurship in Georgia, so such organizations operate within the legal framework of commercial and non-profit organizations.

It should be noted that the active work of organizations that support social entrepreneurship in Georgia (eg, Global Initiative - Tbilisi) 1 and increasing the role of social entrepreneurs at the expense of the social impact they have achieved in society, it has a positive impact on creating favorable conditions for the development of social entrepreneurship in the country. In addition, liberal tendencies are considered as a positive factor for the development of social entrepreneurship in Georgia, which, as in many other countries, has led to state interference in the lives of people becoming increasingly restricted. Social areas traditionally attached to the state (eg education, medicine, etc.) have become more "open".

Inadequate development of socio-economic institutions (small entrepreneurship, credit co-operation, microfinance, non-profit activities in the socio-economic field) are considered as hindering the development of social entrepreneurship. assume that the development of social entrepreneurship in Georgia due to the low rate of the social importance of the intervention of business and there is no tradition of the role of the state primarily by awarding appropriate institutional environment does not exist, and that the social innovations by entrepreneurs not considered as a source of competitive advantage.

The potential for social entrepreneurship to develop in Georgia is enormous if we focus on the growing social problems on the one hand, and on the other, realize the ineffectiveness of using traditional state and market mechanisms to solve social problems. An important prerequisite for the further formation of a favorable institutional environment for social entrepreneurship is to behave as the object of the general social attention of social entrepreneurship in terms of both scientific research and socio-economic transformation.

\footnotetext{
${ }^{1}$ The mission of the social enterprise Arbo, founded by the organization, is to socialize probationers, retirees and the disabled by making children safe and environmentally friendly wooden toys.
} 


\section{Conclusion}

Global trends in the sector of non-profit organizations, the transformation of the concept of corporate social responsibility and the search for sustainable development by companies are also relevant for Georgia. However, the Georgian specifics of the institutional environment (in most cases the low efficiency of business social programs, the short period of development of the nonprofit sector, the low rate of entrepreneurial activity) are due to the so-called "Fragmented" development of social entrepreneurship in Georgia. Formation and development of this new event for social entrepreneurship - for Georgia should be carried out under the proactive and mutually agreed actions of business, state and society.

We may conclude that there is no region in the world that has nothing to do with the spread of social entrepreneurship. It is clear that no participant of the economic system can ignore this event in the modern stage. However, the process of formation and development of social entrepreneurship in different countries is not equal and is characterized by national specificity. Social Entrepreneurship - is an event that is usually bounded by contextual frameworks, and therefore the practice of social entrepreneurship must be disseminated in the light of an accurate analysis of the developmental features and regularities of the region concerned, in order to achieve maximum effect.

\section{References}

[1] 2006. "Fostering social entrepreneurship: a comparative study : a summary of recommendations for governments, policymakers and social entrepreneurs in Brazil, Germany, India, Poland, UK and USA: paper presented at the World Economic Forum in Davos." London. 8.

[2] 2006. "Human Development Report."

[3] 2006. "Social enterprise: making a difference." Harvard Business Review Latin America.

[4] 2008. Social Enterprise: New Model for Poverty Reduction and Employment Generation. EMES \& UNDP report.

[5] 2008. The general report on social enterprise in China. Cultural and Educational Section British Embassy.

[6] 2010. "Global Entrepreneurship Monitor."

[7] 2015. A map of social enterprises and their eco-systems in Europe. Final report.

[8] Austin, James, and Ezequiel Reficco. 2009. Corporate social entrepreneurship. Cambridge: Harvard Business School. 
[9] Boschee, Jerr. 2001. "Eight basic principles for nonprofit entrepreneurs." Nonprofit World 15-18.

[10] Christie, M J, and Honing. 2006. "Social entrepreneurship: new research findings." Journal of World Business 1-5.

[11] Christie, Michael, J. 2006. "Social entrepreneurship: new research findings." Journal of World Business 1-5.

[12] David Rockefeller Center for Latin American Studies, Harvard Universit. 2006. Social enterprise: making a difference. Cambridge: ReVista : Harvard Business Review Latin America; Fall 2006.

[13] Dees, Gregory J, and Beth B Anderson. 2006. "Framing a theory of social entrepreneurship: building on two schools of practice and thought." ARNOVA Occasional Paper Series 1-28.

[14] Dees, Gregory J. 2001. "The meaning of social entrepreneurship." http://www.caseatduke.org/documents/dees_sedef.pdf.

[15] Defourny, Jacques, and Marthe Nyssens. 2008. "Social enterprise in Europe: recent trends and developments." Social Enterprise Journal 202-228.

[16] Defourny, Jacques, and Marthe Nyssens. 2010. "Conceptions of social enterprise and social entrepreneurship in Europe and the United States: convergences and divergences." Journal of Social Entrepreneurship 32-53.

[17] https://en.wikipedia.org/wiki/Grameen_Bank. https://en.wikipedia.org/wiki/Grameen_Bank.

[18] https://in.thehackerstreet.com/social-entrepreneurs-2/. https://in.thehackerstreet.com/social-entrepreneurs-2/.

[19] https://skoll.org/skoll-world-forum/about/. http://skoll.org/skoll-worldforum/about/.

[20] https://startup.fukuoka.jp/. https://startup.fukuoka.jp/.

[21] https://www.zakat.org/en/.

[22] Kerlin, Janelle A. 2006. "Social entreprise in the United States and Europe: understanding and learning from the differences." International Society for ThirdSector Research and The Johns Hopkins University 247-263.

[23] Kerlin, Janelle A. 2009. "Social enterprise: a global comparison." Tufs University Press 211.

[24] Mair, Johanna, and Ignasi Marti. 2006. "Social entrepreneurship research: a source of explanation, prediction, and delight." Journal of World Business 644.

[25] Neuman, Laurence W. 2003. "Social research methods : qualitative and quantitative approaches." 131. Boston: Allyn and Bacon. 
[26] Nicholls, Alex. 2006. "Social entrepreneurship - New Models of Sustainable Social Change." Oxford University Press 1-35.

[27] Nicholls, Alex. 2010. "The legitimacy of social entrepreneurship: reflexive isomorphism in a pre-paradigmatic field." In Entrepreneurship Theory and Practice, by Alex Nicholls, 611-633.

[28] Osterwalder, Alexander, and Yves Pigneur. 2010. "Business model generation: a handbook for visionaries, game changers, and challengers." 288. Hoboken: $\mathrm{NJ}$ : Wiley.

[29] Sesan, Gbenga. 2006. " Social enterprise in Africa : an emerging concept in an emerging economy." International NGO Journal 4-8.

[30] Urban, B. 2008. "Social entrepreneurship in South Africa." International Journal of Entrepreneurial Behavior \& Research 346-364.

[31] www.muslimaid.org. https://www.muslimaid.org.

[32] www.nb-fund.ru. www.nb-fund.ru.

[33] www.tatasechallenge.org. http://www.tatasechallenge.org/.

[34] Yunus, Muhammad. 2010. "Building social business models : lessons from the Grameen experience." In Long Range Planning, by Muhammad Yunus, Bertrand Moingeon and Laurence Lehmann-Ortega, 308-325.

[35] Арай, Юлия Н. 2010. "Социальное предпринимательство: проблемы типологии (предисловие к разделу)." Вестник. 